\title{
注射用セファピリンナトリウムの安定性*1
}

\author{
藤井忠男, 荒井美治, 久保田昭恵, 水島規子 \\ 東海大学病院薬浏部*2
}

\section{Stability of Cefapirin Sodium for Injection*1}

\author{
Tadao FujiI, Yoshiharu ARai, Akie Kubota, and Noriko Mizushima \\ Department of Pharmacy, Tokai University Hospital*2
}

(Received August 18, 1980)

\begin{abstract}
Stability of cefapirin sodium (CEPR), a cephalosporin antibiotic, in 15 different infusion solutions and in an aqueous solution was studied with high-pressure liquid chromatography. It was found that the compound was quite stable in the infusion solutions for 6 hours at room temperature, and may be feasible for regular drip infusion. Des CEPR or CEPR lactone with low anti-bacterial activity was produced as CEPR degraded in solutions at $\mathrm{pH} 10$ or 2 .
\end{abstract}

セファピリンナトリウムの水溶液中での安定性につい ては, $\beta$-ラクタム環の開裂, あるいは構造上, セファロ チンと同様に 3 位のエステル結合が分解したデスアセチ ルセファピリン，およびその縮合体であるデスアセチル セファピリンラクトンの生成なども予想される る1-4). 今 回, 当院において比較的繁用されている輸液 15 種を選 び, セファピリンナトリウムの輸液中での安定性, およ び分解生成物についての検討を行ったので報告する.

\section{実 験 の 部}

試 料 本実験に用いた試料を表 1 亿示す（149 頁参 照).

\section{1. 試料液の眮製}

1) セファピリンナトリウム (1g 力価/1 $\mathrm{V}$, セファト レキシールを使用, 以下 CEPR と略す) $1 \mathrm{~V}$ を注射用 蒸留水 $10 \mathrm{ml}$ で溶解し, 各輸液 $500 \mathrm{ml}$ と配合した液 (0.2\%). 2) CEPR $1 \mathrm{~V}$ を注射用蒸留水 $10 \mathrm{ml}$ で溶解 した液 (10\%)．3） CEPR 1V を蒸留水 $500 \mathrm{ml}$ 飞溶解

*1 日本薬学会第100年会 (東京, 1980年) で発表.

*2 神奈川県伊勢原市下粕屋字上ノ台 $143 ; 143$, Azakaminodai, Shimokasuya, Isehara, Kanagawa, 259-11 Japan<smiles>CC(=O)OCC1=C(C(=O)O)N2C(=O)C(NC(=O)CSc3ccncc3)C2SC1</smiles>

Cefapirin<smiles>O=C(CSc1ccncc1)NC1C(=O)N2C(C(=O)O)=C(CO)CSC12</smiles>

Desacetyl Cefapirin.<smiles>O=C(CSc1ccncc1)NC1C(=O)N2C3=C(COC3=O)CSC12</smiles>

Desacetyl Cefapirin lactone

したのち，0.1 NHCl および $0.1 \mathrm{NNaOH} て ゙ \mathrm{pH} 2, \mathrm{pH} 10$ に維持した液.

以上の試料液について，それぞれ外観観察， $\mathrm{pH}$ 測定， 紫外部吸収スペクトル測定による変化，薄層クロマトク 
ラフィー, 高速液体クロマトグラフィーによる分離, 定 量を行った。

\section{2. 外観観察および $\mathbf{p H}$ 測定}

まず，各試料の $\mathrm{pH}$ を測定し，つついて配合直後， 6 時間, 24 時間後の $\mathrm{pH}$ 測定, および色調の変化, 沈殿の 有無について観察した.

\section{3. 紫外部吸収スペクトル}

CEPR の含量が $20 \mu \mathrm{g} / \mathrm{ml}$ 濃度になるように試料液を 希釈し，水を対照として 350〜220 nm に゙おける紫外部 吸収スペクトルを測定した。

\section{4. 高速液体クロマトグラフィーによる含专湘定}

装置 : LC830 型 (島津), UV 検出器 (254 nm, 0.04 AUFS).

カラム：マイクロボンダパック $\mathrm{NH}_{2}$ (ウォーターズ). 分析溶媒: 酢酸/メタノール/アセトニトリル/水 (2/4/50/44).

流速 : $1 \mathrm{ml} / \mathrm{min}$

内部標準 : ニュチン酸（注入量 $0.8 \mu \mathrm{g}$ ).

試料液を CEPR 含量 $20 \mu \mathrm{g} / \mathrm{ml}$, ニュチン酸含量 40 $\mu \mathrm{g} / \mathrm{ml}$ になるように希釈し, 希釈液 $20 \mu \mathrm{l}$ を注入して, 5.5 分に溶出する CEPR, 9.5 分に溶出するニコチン酸 のピーク高さ比より CEPR の含量を測定した．図 1 (a) に示すように, 濃度比とピーク高さ比は, きわめて 良好な直線性を示した。

\section{5. 分解物の検索}

\section{a）分解物の合成}

デスアセチルセファピリン（以下 des CEPR と略す） :ブリストル社よりナトリウム塩の提供を受けた. デス アセチルセファピリンラクトン（以下 CEPR lactone と略す) : NEIDLEMAN 等ら) の方法に準じて合成した. CEPR $0.6 \mathrm{~g}$ を水 $6 \mathrm{ml}$ で溶かし,アセトン $5 \mathrm{ml}$, 濃塩 酸 $2 \mathrm{ml}$ を加え室温で 8 時間攪拌したのち析出晶をろ取, アセトン洗浄, メタノールより再結晶して, $\operatorname{mp~} 223^{\circ}$ (decomp.) の CEPR lactone 塩酸塩 $0.3 \mathrm{~g}$ を得た. Anal. Calcd. $\mathrm{C}_{15} \mathrm{H}_{13} \mathrm{~N}_{3} \mathrm{O}_{4} \mathrm{~S}_{2} \cdot \mathrm{HCl}: \mathrm{C}, 45.06 ; \mathrm{H}, 3.53$; $\mathrm{N}, 10.51$. Found. C, $45.03 ; \mathrm{H}, 3.55 ; \mathrm{N}, 10.46$.

b）高速液体クロマトグラフィー（以下 HPLC と略 す）による分解物の定量

図 1 (b ) に示すように， 7 分に溶出する des CEPR 2.5 分に溶出する $\mathrm{CEPR}$ lactone $\mathrm{CEPR}$ と同時分離 定量した.

c）薄層クロマトグラフィー（以下 TLC と略す）に よる分解物の確認

薄層プレート：キェーゼルゲル $\mathrm{F}_{254}$ (メルク，厚さ

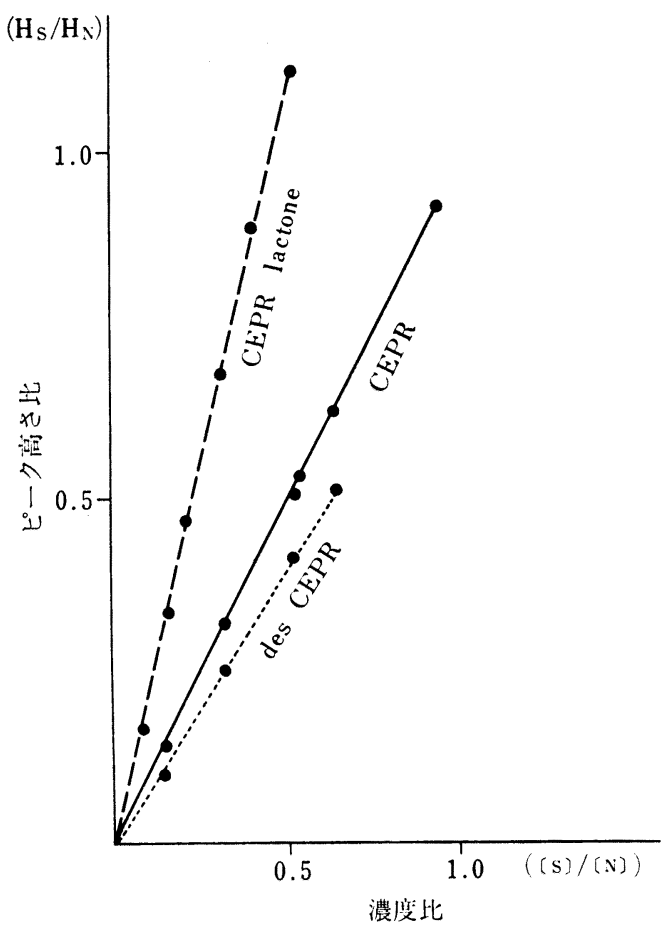

図1(a). CEPR および分解物の検量線 (HPLC)

$0.25 \mu)$.

展開溶媒 : 酢酸エチル／アセトン／酢酸／水 $(5 / 2 ／$ $1 / 1)$.

CEPR の濃度 $2 \mathrm{mg} / \mathrm{ml}$ の試料液を $10 \mu 1$ スポットし, 約 $10 \mathrm{~cm}$ 展開後, 風乾し, UV ランプおよびョウ素蒸気 で呈色させた. des CEPR, CEPR lactone の検出限界 は，それぞれ $2 \mu \mathrm{g} ， 1 \mu \mathrm{g}$ である。

\section{6. 力価測定}

日抗基に準じ，Bacillus subtillis ATCC 6633 を試験 菌に用い,円筒平板法で力価を測定し, des CEPR, CEPR lactone の力価を CEPR と比較検討した.

\section{䊅果と考寮}

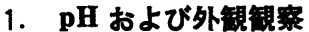

$\mathrm{pH}$ の変動について表 2 に示した。 $\mathrm{pH}$ 変動試験では, いずれの注射剤も配合に注意を要するものは認められな かった．配合直後の $\mathrm{pH}$ が CEPR の水溶液に近い $\mathrm{pH}$ 示した配合液において，経時やや $\mathrm{pH}$ の低下が認められ た. 肉眼的な外観観察においては, 配合直後, いずれの 試料も微黄色を呈し，24 時間後にわずかに濃色化が認 められた。 


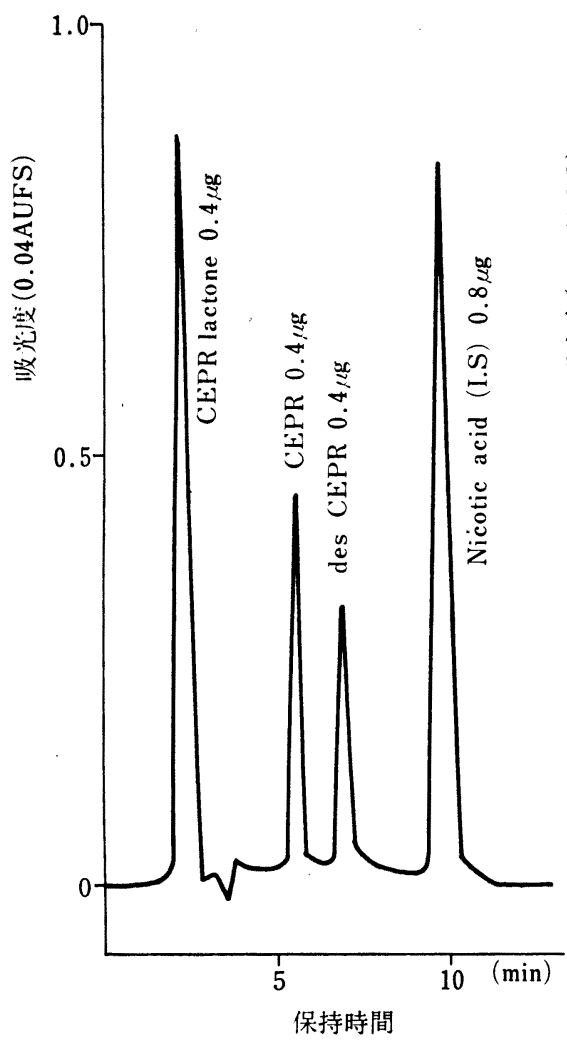

標準物質の分離

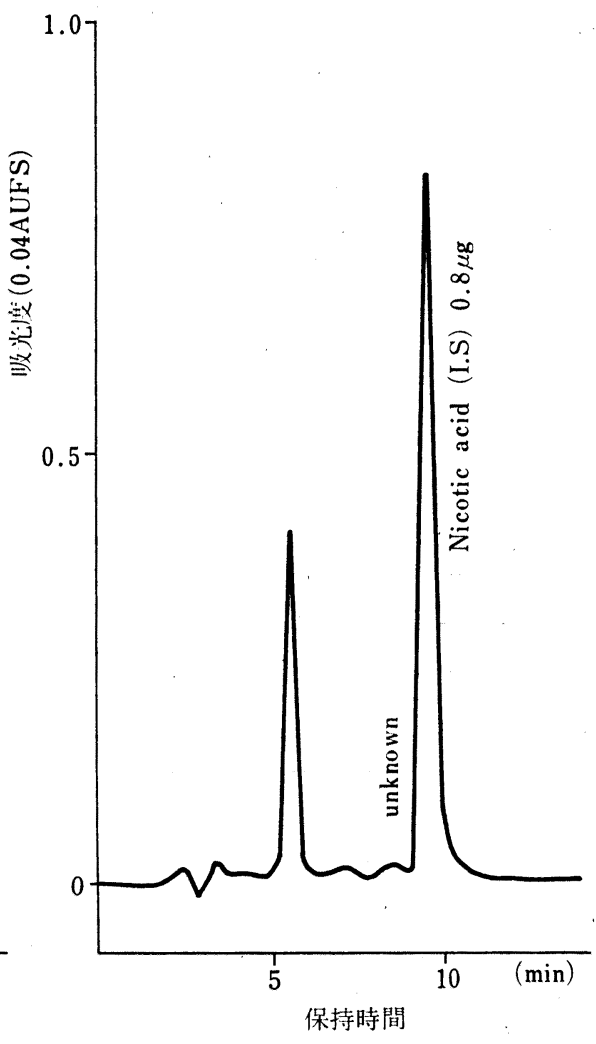

溶解後 24 時間

図 1(b). CEPR および分解物のクロマトグラ (HPLC)

表 1. 本実酫に用いた試料

\begin{tabular}{|c|c|c|c|}
\hline 品 & 製 造 元 & 規 格 & Lot. 番号 \\
\hline フィシザルッ & 扶 & $500 \mathrm{ml}$ & 31622 \\
\hline リンゲル液 & 大 & 500 & 9G710 \\
\hline ハルトマン液 $\mathrm{pH} 8$ & $ミ ト ゙ リ$ & 1000 & 377 R H \\
\hline ラクテック & 大塚 & 500 & K8 J 79 \\
\hline ラクテック G & 大 & 500 & K $8 \mathrm{~K} 98$ \\
\hline ポタコール R & 大 & 500 & 9 I 840 \\
\hline フルクトラクト & 大 & 500 & 8 I 99 \\
\hline ソリタ T 3 & 清 & 500 & A3KFI \\
\hline ソリタ T $3 \mathrm{G}$ & 清 & 500 & $\mathrm{~A} 4 \mathrm{HCA}$ \\
\hline フィジオゾール 3 号 & ミドリ & 500 & 714 R G \\
\hline $5 \%$ ル゙ルン & 扶 & 500 & D V 317 \\
\hline $10 \%$ 大塚糖液 & 大 & 500 & $8 \mathrm{~J} 702$ \\
\hline $5 \%$ リ ニット & エーザイ & 500 & B10HDA \\
\hline マルトス10 & 大 & 500 & К9H 72 \\
\hline グリセオール & 中 & 500 & A9G06 \\
\hline 注射用蒸留水 & 院内㡀䑤 & 500 & \\
\hline 注射用蒸留水 & 扶 桑 & 5 & 40930 \\
\hline 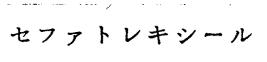 & $\begin{array}{l}\text { 日本 } \\
\text { ブリスト }\end{array}$ & ( & F 8V03 \\
\hline
\end{tabular}

表 2. CEPR 配合輸液の $\mathrm{pH}$ 経時変化

\begin{tabular}{|c|c|c|c|c|}
\hline $\begin{array}{c}10 \% \text { CEPR } \\
\text { (CEPR 1V+ } \\
\text { 注射用蒸留 }\end{array}$ & $10 \mathrm{ml})$ & $\begin{array}{r}\text { 溶解時 } \\
6.87\end{array}$ & -2 & 間後 \\
\hline 輸 & $\begin{array}{c}\text { 配合前 } \\
\mathrm{pH}\end{array}$ & $\begin{array}{l}500 \mathrm{ml}+ \\
\text { 配合時 }\end{array}$ & $\begin{array}{l}-10 \% \mathrm{CE} \\
6 \text { 時間 } \\
\text { 後 }\end{array}$ & $\begin{array}{r}\mathrm{PR} 10 \mathrm{ml} \\
24 \text { 時間 } \\
\text { 後 } \\
\end{array}$ \\
\hline フィジオゾール 3 号 & 4.36 & 4.94 & 4.90 & 4.88 \\
\hline フルクトラクト & 4.63 & 5.43 & 5.38 & 5.36 \\
\hline ポタコール R & 4.84 & 5.58 & 5.56 & 5.53 \\
\hline ソリタ T $3 \mathrm{G}$ & 5.09 & 5.91 & 5.88 & 5.82 \\
\hline ソリタ T 3 & 5.14 & 5.96 & 5.90 & 5.87 \\
\hline グリセオール & 3.91 & 6.27 & 6.22 & 6.08 \\
\hline $10 \%$ 大塚糖液 & 4.49 & 6.57 & 6.53 & 6.25 \\
\hline リンゲル液 & 6.52 & 6.60 & 6.50 & 6.31 \\
\hline マルトス 10 & 4.54 & 6.61 & 6.54 & 6.25 \\
\hline $5 \%$ グルノン & 4.86 & 6.72 & 6.58 & 6.30 \\
\hline $5 \%$ クリニット & 6.11 & 6.78 & 6.63 & 6.32 \\
\hline フィシザルッ & 5.96 & 6.80 & 6.61 & 6.34 \\
\hline 注射用蒸留水 & 6.73 & 6.81 & 6.64 & 6.32 \\
\hline ラクテック $\mathrm{G}$ & 6.56 & 6.81 & 6.67 & 6.41 \\
\hline ラクテック & 6.58 & 6.85 & 6.69 & 6.43 \\
\hline ハルトマン pH 8 & 8.04 & 7.22 & 6.98 & 6.62 \\
\hline
\end{tabular}



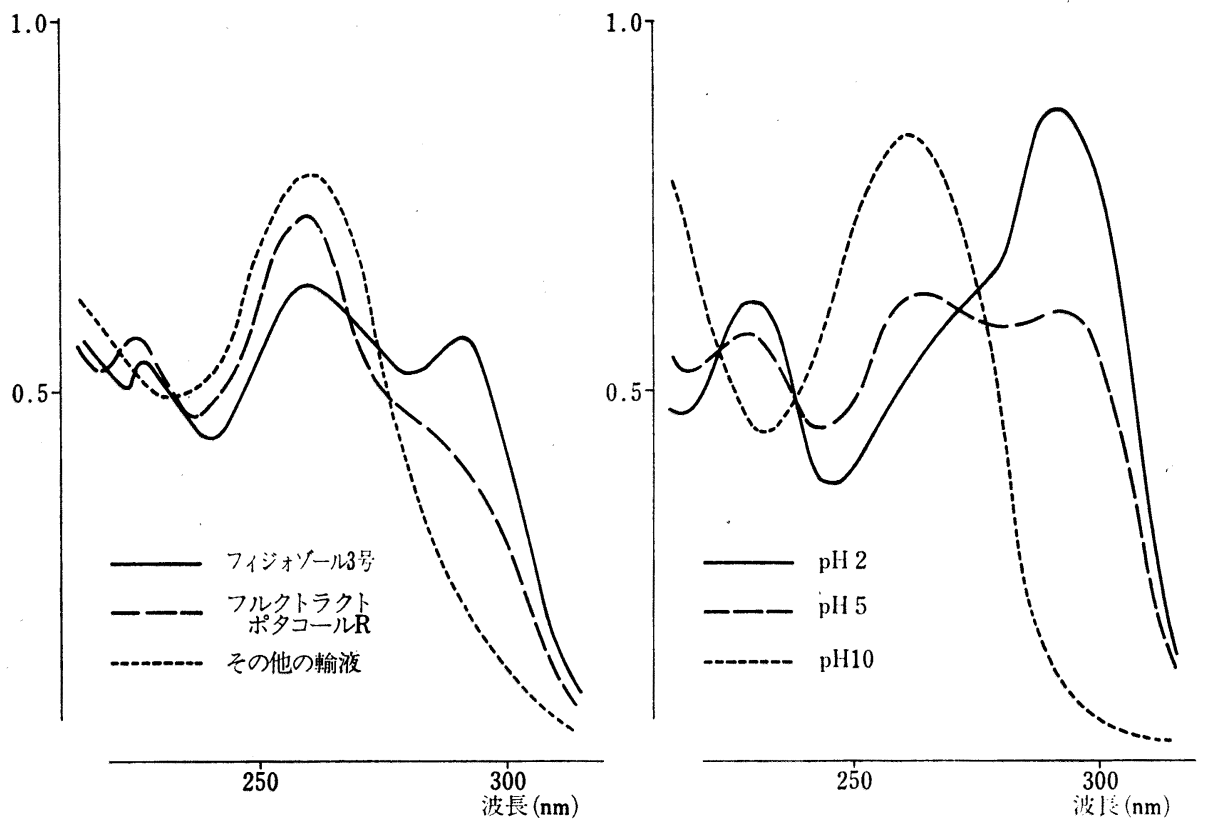

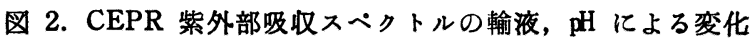

表 3. 各種輸液中における CEPR 残存率 $(0.2 \%)$

\begin{tabular}{|c|c|c|}
\hline 輸 液 & 6 時間後 & 24時間後 \\
\hline ラクテック G & $100.0(\%)$ & $100.0(\%)$ \\
\hline ソリタ T 3 & 100.0 & 95.9 \\
\hline ラクテック & 92.7 & 95.4 \\
\hline マルトス 10 & 95.5 & 94.6 \\
\hline $10 \%$ 大塚糖液 & 95.2 & 94.3 \\
\hline フィシザルッ & 91.7 & 92.6 \\
\hline リンゲル液 & 97.9 & 91.2 \\
\hline $5 \% ク リ=ッ ト$ & 94.5 & 91.1 \\
\hline ポタコール R & 98.6 & 90.9 \\
\hline $5 \%$ グルン & 96.6 & 90.6 \\
\hline ソリタ T $3 \mathrm{G}$ & 96.6 & 89.9 \\
\hline フルクトラクト & 91.7 & 89.9 \\
\hline 注射用蒸留水 & 95.3 & 89.8 \\
\hline ハルトマン $\mathrm{pH} \cdot 8^{*}$ & 96.6 & 89.5 \\
\hline クリリセオール & 97.1 & 89.0 \\
\hline フィジオソール 3 号 & 98.7 & 88.9 \\
\hline
\end{tabular}

* 1 ボトル $(1000 \mathrm{ml})$ 中より $500 \mathrm{ml}$ を抜きとった のち混合した。

\section{2. 紫外部吸収スペクトル}

図 2 の右側には $\mathrm{pH}$ にる CEPR の紫外部吸収スペク トルの変動を, 左側には試料液の配合直後の紫外部吸収 スペクトルを示した。

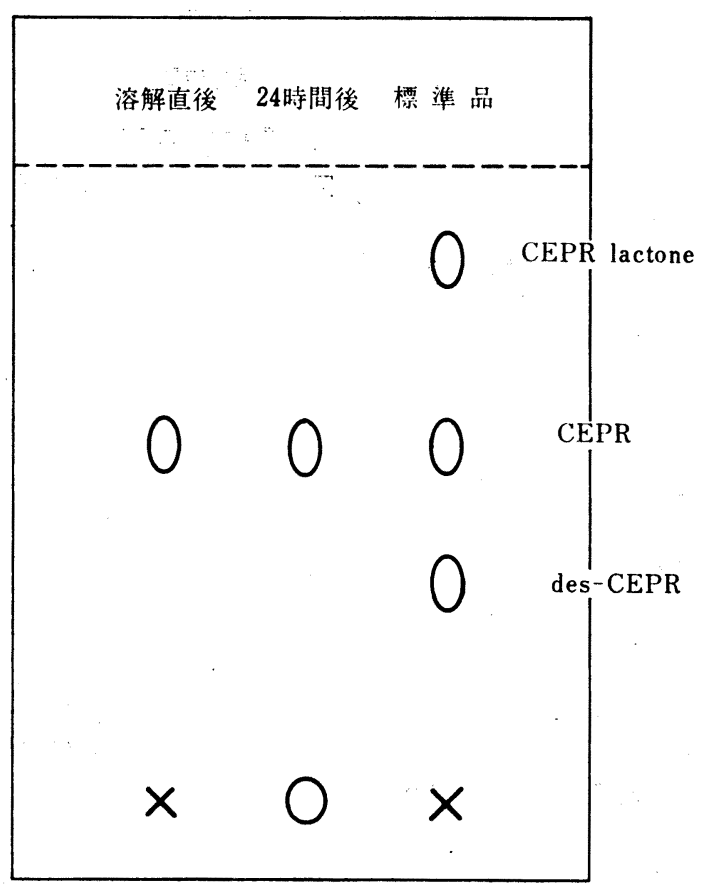

図 3. CEPR および分解物のクロマトグラム (TLC) 検出 (UV, I $\left.I_{2}\right)$

各輸液は測定 濃度で紫外部に吸収を認めなかった。 ほとんどの輸液中で CEPR と配合直後, 水溶液中の 
表 4. CEPR 10\% 水溶液中の残存率

\begin{tabular}{l|r|rrl}
\hline 保 存 & 条 件 & 6 時間 & 24時間 & \multicolumn{1}{c}{ 48時間 } \\
\hline 散光下 & $25 \pm 2^{\circ}$ & $94.3(\%)$ & $79.3(\%)$ & $64.5(\%)$ \\
㵂 光 & $25 \pm 2^{\circ}$ & 95.9 & 79.5 & 66.8 \\
散光下 & $5 \pm 1^{\circ}$ & 100.0 & 98.4 & 98.0 \\
\hline
\end{tabular}

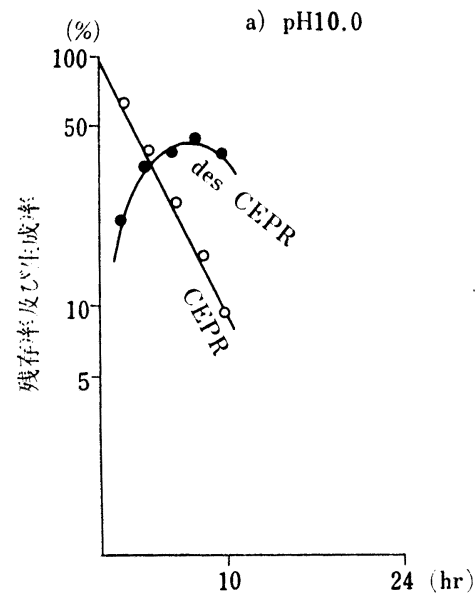

CEPR の紫外部吸収スペクトルと同様のチャートを示 しているが, 门ルクトラクト，フィジオゾール 3 号, ポタコール R 中では異なったチャートを示している.

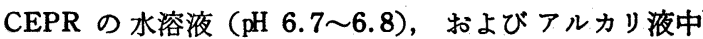
では 260〜262nm に吸収極大をるつが，pH 低下に伴い 吸収極大が $290 \mathrm{~nm}$ 付近に移動することにより. 低 $\mathrm{pH}$ (

図 4. $\mathrm{pH} 2$ および 10 での CEPR の分解と分解物の生成 $\left(35^{\circ}\right)$ （pH は $0.1 \mathrm{NHCl}, 0.1 \mathrm{NNaOH}$ により調整）

イジオゾール 3 号 4.94, フルクトラクト 5.43, ポタュ 一ルR5.58）による変化と思われる.なお，この変化に は含量変化や分解物の生成を伴っていないことを HPLC および TLC で確認した. 各試料液は24時間後も紫外部 吸収スペクトルに変化は認められなかった。

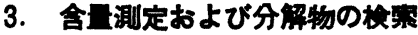

表 3 に, 配合值後の試料液中の CEPR の含量を 100 \%とし 6 時間および24時間後の残存率を示した。 6 時間 後においては，いずれる90\%以上の含量を維持し，24時 間後にも90\%以上あるいは90\%近い含量を示した. 図 1 （b）に示した HPLC では 24 時間後の水溶液および輸 液中での $0.2 \%$ 試料液中に, 7 分に溶出する des CEPR と 8.5 分に溶出する未知物質がわずかであるが検出され た. 図3に示すTLCでは, 配合直後にはいずれの試料 液中においても，分解物のスポットを検出しなかった。 24 時間後に原点付近にヨウ素および UV ランプにて呈 色する物質を検出したが，同定できなかった．表 4 に10 $\% \mathrm{CEPR}$ 液の遮光および温度の影嫼について検討した 結果を示した. 能畫では室温暗所で48時間以内に使用す る旨記載してあるが，この結果においては，遮光保存の 奻果はあまりなく, むしろ冷所保存した方が好ましいと
考える. 図 4 に $0.2 \% \mathrm{CEPR}$ 水溶液を $0.1 \mathrm{NHCl} て ゙ \mathrm{pH}$ 2 に, $0.1 \mathrm{~N} \mathrm{NaOH}$ で $\mathrm{pH} 10$ に維持し, 経時的に含昷の 測定を行った結果を示した. CEPR の含量低下に伴い， pH 10 では des CEPR の生成が, pH 2 では CEPR lactone の生成が認められた．特にアルカリ性における 3 位のエステル結合の分解は著しいと思われる。

\section{4. 分解物の抗暴活性}

常用標準セファピリンナトリウム (960mg 力価/1 g.) を用いて力価測定を行った結果, CEPR の力価 100 に対 し, des CEPR は22. 4, CEPR lactone は 27.1 であ ク，約 $1 / 4$ の抗菌活性しか示さなかった。

\section{結}

今回，試験を行った輸液中では，いずれる CEPR と 配合不適なるのは認められず，配合後 6 時間では $90 \%$ 以上の含量る保たれ, 分解物の生成る認められないこと より，通常の点滴使用には問題ないと思われる。たた し, 抗菌活性の低い des CEPR, CEPR lactone の生成 が予想されるので, 高 $\mathrm{pH}$, 低 $\mathrm{pH}$ の注射薬との配合, あ るいは配合後の保存は避けた方が望ましい。 


\section{参考 文 献}

1) C. H. Nightingale, D. S. Greene, and R. Quintiliani : J. Pharm. Sci., 64, 1899 (1975).

2) V. K. Prasad, A. P. Granatek, and M. M. Mihotic : Curr. Ther. Res., 16, 505 (1974).
3) V. K. Prasad, A. P. Granatek, and M. M. Mihotic: Curr. Ther. Res., 16, 540 (1974).

4) T. Yamana and A. Tsuji : J. Pharm. Sci., 65, 1563 (1976).

5) S. L. Neidleman, S. C. Pan, J. A. Last, and J. E. Dolfini : J. Med. Chem., 13, 386 (1970).

\section{一流品にふさわしい一流品との出合い。 MILLIPORE \& NIKKA 製剂専用クリーンベンチ}

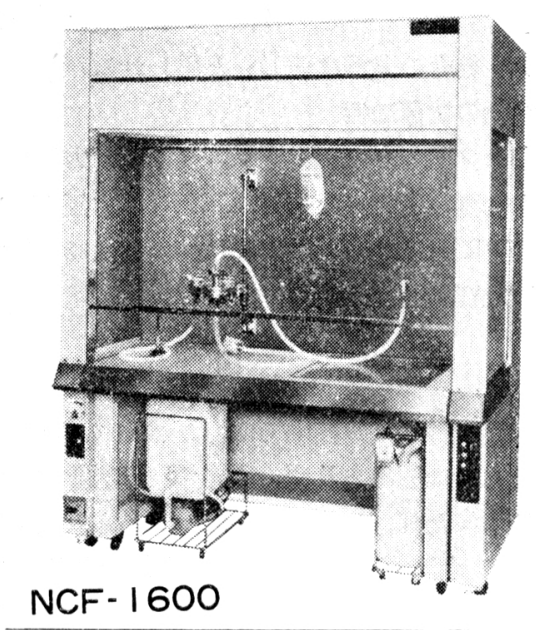

NCF -1600
特に病院の製剂専用に開発された クリーンベンチで、今では多くの 病院で使われています。

\section{（主要納入先）}

東京大学病院分院 - 東北大学抗研病院 東京厚生年金病院・東京虎の門病院・ 東京医大病院 - 豊橋市民病院 - 兵庫医 大病院・広島大学病院・国立善通寺病 院・九州厚生年金病院様 〔順不同〕 詳しくはカタログをご請求下さい 